\title{
Pemberdayaan Masyarakat Melalui Pembinaan Kelompok Perikanan Dalam Meningkatkan Kesejahteraan Masyarakat
}

\author{
Iswadi \\ Fakultas Ushuluddin, Adab dan Dakwah IAIN Batusangkar \\ (E-mail: iswadi@iainbatusangkar.ac.id)
}

\begin{abstract}
The purpose of this study was to determine the implementation of fisheries group empowerment, supporting and inhibiting factors, the research approach used was descriptive qualitative. The subjects of the study were: the 'Sarai Mandiri' fish cultivator group, stakeholders and community leaders. Data collection through: interviews, observation, and documentation. Data analysis was carried out through the stages of data reduction, data presentation, and drawing conclusions. Test the validity of research data by using triangulation. The results revealed that the implementation of community empowerment was carried out through the 'Mandiri Saiyo' fish cultivator group, namely: changing the mindset of the community towards fish farming, providing knowledge about good and right fish farming and providing skills related to feed making, empowering supporting factors namely: support from the community, government, community enthusiasm and strategic location, while the inhibiting factors are: lack of organizational management, lack of awareness of group members, lack of teamwork and marketing of yields, the results of implementing empowerment of increased community stimulus to use their land for fish farming, employment increase and reduce unemployment, increase member income, increase knowledge about fish farming and increase the ability to make feed.
\end{abstract}

Keywords: Empowerment, fish cultivator

Abstrak: Tujuan dari penelitian ini adalah untuk mengetahui pelaksanaan pemberdayaan kelompok perikanan, faktor pendukung dan penghambat, pendekatan penelitian yang digunakan adalah deskriptif kualitatif. Subjek penelitian adalah: kelompok pembudidaya ikan 'mandiri saiyo', stakeholder dan tokoh masyarakat. Pengumpulan data melalui: wawancara, observasi, dan dokumentasi. Analisis data dilakukan melalui tahapan reduksi data, penyajian data, dan penarikan kesimpulan. Uji validitas data penelitian dengan menggunakan triangulasi. Hasil penelitian mengungkapkan pelaksanaan pemberdayaan masyarakat dilakukan melalui kelompok pembudidaya ikan 'Mandiri Saiyo' yaitu: mengubah pola pikir masyarakat terhadap budidaya ikan, memberikan pengetahuan tentang budidaya ikan yang baik dan benar serta memberikan keterampilan terkait dengan pembuatan pakan, faktor-faktor pendukung pemberdayaan yaitu: dukungan dari masyarakat, pemerintah, antusias masyarakat dan lokasi yang 
2 Iswadi, Pemberdayaan Masyarakat Melalui Pembinaan Kelompok Perikanan Dalam Meningkatkan Kesejahteraan Masyarakat

Jurnal At-Taghyir : Jurnal Dakwah dan Pengembangan Masyarakat Desa

Volume 2 Nomor 1 Desember 2019, h. 1-13

strategis, sementara faktor penghambat adalah: kurangnya manajemen organisasi, kurangnya kesadaran anggota kelompok, kurangnya kerja tim dan pemasaran hasil panen, hasil pelaksanaan pemberdayaan meningkatnya stimulus masyarakat untuk menggunakan lahan mereka untuk budidaya ikan, lapangan kerja meningkat dan mengurangi pengangguran, meningkatkan pendapatan anggota, meningkatkan pengetahuan tentang budidaya ikan dan meningkatkan kemampuan untuk membuat pakan.

Kata Kunci: Pemberdayaan, Pembudidaya Ikan

\section{A. Pendahuluan}

Dalam mewujudkan kesejahteraan masyarakat Indonesia termaktub dalam pembukaan UUD 1945 yaitu membentuk suatu pemerintahan Negara Republik Indonesia yang melindungi segenap bangsa Indonesia dan seluruh tumpah darah Indonesia, memajukan kesejahteraan umum/bersama, mencerdaskan kehidupan bangsa, ikut berperan aktif dan ikut serta dalam melaksanakan ketertiban dunia yang berlandaskan kemerdekaan, perdamaian abadi dan keadilan sosial. Dengan demikian pembangunan nasional diharapkan mampu menuju pada keseimbangan, keserasian, dan keselarasan dalam kehidupan masyarakat. ${ }^{1}$ Salah satu unsur yang esensial dari pembangunan masyarakat yaitu adanya proses perubahan. Perubahan yang dimaksud dapat merupakan perubahan alami yang tumbuh dari dinamika masyarakat itu sendiri, dapat pula merupakan perubahan yang terencana. ${ }^{2}$ Untuk itu diperlukan suatu gebrakan nyata dalam mewujudkan nilai-nilai luhur bangsa yang bercita-cita mensejahterahkan kehidupan bangsa sebagaimana yang tertuang dalam pembukaan UUD 1945 dapat terwujud.

Pemberdayaan masyarakat (empowerment) sebagai strategi alternative dalam pembangunan telah berkembang dalam berbagai literatur dan pemikiran walaupun dalam kenyataannya belum secara maksimal dalam implementasinya. Pembangunan dan pemberdayaan masyarakat merupakan hal banyak dibicarakan masyarakat karena terkait dengan kemajuan dan perubahan bangsa ini kedepan apalagi apabila dikaitkan

\footnotetext{
${ }^{1}$ Nana Sudjana, Nana, Dasar-dasar Proses Belajar Mengajar, (Bandung: Sinar Baru Algensido Offset, 2004), hlm. 148

2 Soetomo, Strategi-strategi Pembangunan Masyarakat, (Yogyakarta, Pustaka Pelajar, 2006), hlm. 44
} 
3 Iswadi, Pemberdayaan Masyarakat Melalui Pembinaan Kelompok Perikanan Dalam Meningkatkan Kesejahteraan Masyarakat

Jurnal At-Taghyir : Jurnal Dakwah dan Pengembangan Masyarakat Desa

Volume 2 Nomor 1 Desember 2019, h. 1-13

dengan skill masyarakat yang masih kurang akan sangat menghambat pertumbuhan ekonomi itu sendiri. ${ }^{3}$

Keberdayaan dalam konteks masyarakat adalah kemampuan individu yang bersenyawa dalam masyarakat dan membangun keberdayaan masyarakat yang bersangkutan. Memberdayakan masyarakat adalah upaya untuk meningkatkan harkat dan martabat lapisan masyarakat yang dalam kondisi sekarang tidak mampu untuk melepaskan diri dari perangkap kemiskinan dan keterbelakangan. Dengan kata lain memberdayakan adalah memampukan dan memandirikan masyarakat. ${ }^{4}$

Islam adalah agama pemberdayaan, ajaran Islam yang bersumber dari Allah dan Rasul-Nya tidak menginginkan umatnya berada dalam kekufuran. Sehingga dibutuhkan etos kerja yang bagus dan Allah tidak akan merubah keadaan suatu kaum kalau kaum itu tidak mau merubahnya. Dengan kata lain Islam sangat menginginkan umatnya berdaya dalam semua segi kehidupan. Sebagaimana yang tercantum dalam Al-Quran surat Ar-Ra'd : 11

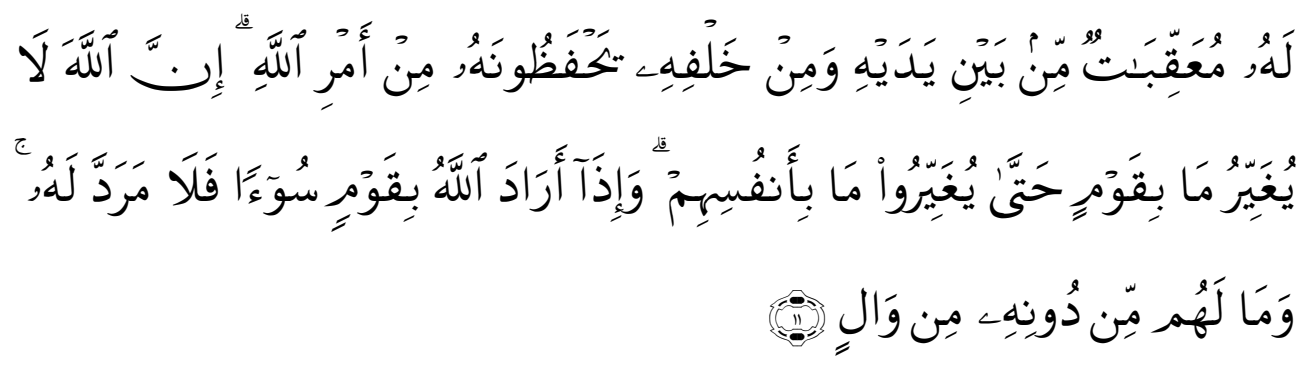

"Bagi manusia ada malaikat-malaikat yang selalu mengikutinya bergiliran, di muka dan di belakangnya, mereka menjaganya atas perintah Allah. Sesungguhnya Allah tidak merubah Keadaan sesuatu kaum sehingga mereka merobah keadaan yang ada pada diri mereka sendiri. dan apabila Allah menghendaki keburukan terhadap sesuatu kaum, Maka tak ada yang dapat menolaknya; dan sekali-kali tak ada pelindung bagi mereka selain Dia."

Dalam pemberdayaan masyarakat, masyarakatlah yang menjadi aktor dan penentu pembangunan. Dalam kaitan ini, usulan-usulan masyarakat merupakan dasar bagi program pembangunan lokal, regional, bahkan menjadi titik pijak bagi program

\footnotetext{
${ }^{3}$ Munawar Noor, Pemberdayaan Masyarakat, Jurnal Ilmiah CIVIS, Volume I, No 2 Tahun 2011, hlm. 88

${ }^{4}$ Arif Eko Wahyudi Arfianto dkk, Pemberdayaan Masyarakat Dalam Pembangunan Ekonomi Desa, JKMP, Vol. 2, No.1 Tahun 2014, hlm. 56
} 
4 Iswadi, Pemberdayaan Masyarakat Melalui Pembinaan Kelompok Perikanan Dalam Meningkatkan Kesejahteraan Masyarakat

Jurnal At-Taghyir : Jurnal Dakwah dan Pengembangan Masyarakat Desa

Volume 2 Nomor 1 Desember 2019, h. 1-13

nasional. Disinilah masyarakat difasilitasi untuk mengkaji kebutuhan, masalah dan peluang pembangunan dan perikehidupan mereka sendiri. Selain itu mereka juga menemukan solusi yang tepat dan mengakses sumber daya yang diperlukan, baik sumber daya eksternal maupun sumber daya milik masyarakat itu sendiri. ${ }^{5}$ usulanusulan yang disampaikan oleh masyarakat tertuang dalam rapat Musrembang yang di adakan oleh Nagari setiap tahunnya, setelah selesai di tingkat Nagari dilanjutkan pada tingkat Kecamatan dan natinya akan bermuara di tingkat Kabupaten. Pada rapat tersebut masyarakatlah yang memutuskan program-program yang akan dilaksanakan oleh pemerintah Nagari dalam mewujudkan kesejahteraan masyarakat.

Dewasa ini sebagian warga masyarakat berada dalam lingkaran kemiskinan, maka perlu adanya kebijakan dan program untuk menunjang masyarakat agar sejahtera dari segi sosialnya. Meninjau dari kebijakan dan program masa lalu cenderung dilaksanakan secara kurang efektif yang di mana jangkauan pelayanan terbatas, lebih mengedepankan pendekatan institusi panti sosial dan dilaksanankan tanpa rencana strategi nasional.

Menurut data statistik Kabupaten Tanah Datar tahun 2018, tentang Indikator Kemiskinan di Kabupaten Tanah Datar, 2013-2017 ${ }^{6}$ memberikan informasi bahwa, jumlah penduduk miskin masih banyak dan Jumlah tersebut juga dipengaruhi oleh belum stabilnya kondisi perekonomian nasional. Sebagai contoh, kondisi di kabupaten tanah datar dari tahun 2013 -2017. Dengan jumlah penduduk miskin di Kabupaten Tanah Datar tahun 2017 berjumlah 19.27 ribu jiwa (5,56\%). Ini menandakan perlunya suatu pemberdayaan di tengah masyarakat untuk meningkatkan kesejahteraan masyarakat di Kabupaten Tanah Datar.

Nagari Andaleh Baruh Bukik berada di Kecamatan Sungayang Kabupaten Tanah Datar. Nagari ini memiliki sumber daya alam yang sangat baik, namun itu semua belum termanfaatkan secara maksimal, Nagari Andaleh Baruh Bukik terletak di kaki gunung sago sehingga sumber air bersih sangat banyak di jumpai disana. Dengan keadaan alam yang begitu bagus tidak berbanding lurus dengan pemanfaatan sumber air dan lahan. Keadaan ini disebabkan oleh beberapa hal; pertama: kurangnya ilmu

\footnotetext{
${ }^{5}$ Mardikanto T dan Soebiato P, Pemberdayaan Masyarakat. (Bandung, Alfabeta, 2013), hlm. 61

${ }^{6}$ Statistik Daerah Kabupaten Tanah Datar, (2017) BPS Kab. Tanah Datar.
} 
5 Iswadi, Pemberdayaan Masyarakat Melalui Pembinaan Kelompok Perikanan Dalam Meningkatkan Kesejahteraan Masyarakat

Jurnal At-Taghyir : Jurnal Dakwah dan Pengembangan Masyarakat Desa

Volume 2 Nomor 1 Desember 2019, h. 1-13

masyarakat dalam membudidayakan ikan, kedua: kurangnya kesadaran masyarakat dalam memanfaatkan sumber daya alam yang melimpah, ketiga: masyarakat hanya terfokus kepada hasil dari bertani. Pada tahun 2016 lahirlah sebuah kelompok pembudidaya ikan yang mencoba untuk memanfaatkan sumber daya alam tersebut. Melalui kelompok pembudidaya ikan dilakukan pembinaan yang tujuannya adalah untuk meningkatkan kemandirian dan kesejahteraan masyarakat. Dengan adanya pemberdayaan tersebut masyarakat yang tidak memanfaatkan lahan kolomnya secara maksimal, bisa dimanfaatkan sebaik-baiknya. Dengan adanya pembinaan dalam membudidayakan perikanan masyarakat lebih terberdayakan dan meningkatnya kesejahteraan masyarakat.

Pada penelitian ini penulis memakai metode riset lapangan (field research), dengan kata lain data dan informasi penulis peroleh secara langsung dari narasumber di lapangan. Data dan Informasi yang akan dicari adalah pembinaan kelompok perikanan untuk meningkatkan kesejahteraan masyarakat di Nagari Andaleh Baruh Bukik Kecamatan Sungayang Kabupaten Tanah Datar. sedangkan teknik pengumpulan data yang penulis pakai adalah: Wawancara, observasi dan dokumentasi. Data yang telah terkumpul kemudian dianalisa dengan berbagai tahapan yaitu, menyeleksi data, mereduksi, mengklasifikasi, memberikode dan menggambarkan atau mendeskripsikan data yang telah di analisa guna menemukan maksud dan tujuan penelitian. agar tidak terjadi kekeliruan pada pengambilan data, kemudian dikelompokkan sesuai dengan aspek permasalahannya. Setelah dikelompokkan, selanjutnya diolah dengan teknik analisa deskriptif kualitatif dan dihubungkan dengan teori sesuai dengan permasalahan penelitian. Untuk menguji dari keabsahan data dilakukan teknik triangulasi yaitu melakukan pengecekan terhadap sumber data dan teori yang terkait dengan penelitian. Proses ini dilakukan terus menerus sampai diyakini tidak ada lagi perbedaan dan yang perlu dikonfirmasikan kepada responden. ${ }^{7}$ Setelah data diuji keabsahannya dan tidak ada lagi kekeliruan maka di tariklah kesimpulan dalam penelitian ini.

\section{B. Pemberdayaan Masyarakat (Empowerment Society)}

Pemberdayaan masyarakat atau Empowerment Society merupakan kreatifitas masyarakat dalam peningkatan kualitas hidup untuk mengatasi berbagai persoalan

\footnotetext{
${ }^{7}$ Burhan Bungin, Analisis Data Penelitian Kualitatif, (Jakarta: Raja Grafindo, 2006), hlm. 192
} 
6 Iswadi, Pemberdayaan Masyarakat Melalui Pembinaan Kelompok Perikanan Dalam Meningkatkan Kesejahteraan Masyarakat

Jurnal At-Taghyir : Jurnal Dakwah dan Pengembangan Masyarakat Desa

Volume 2 Nomor 1 Desember 2019, h. 1-13

dalam bentuk peningkatan kemandirian masyarakat. Untuk meningkatkan kualitas hidup masyarakat diperlukan pengetahuan, ketrampilan dan sikap untuk dapat menyelesaikan persoalan yang hadapi. ${ }^{8}$ Mardikanto $^{9}$ mendefinisikan bahwa community development dalam istilah asing adalah "Proses perubahan sosial, ekonomi dan politik untuk memberdayakan dan memperkuat kemampuan masyarakat melalui proses belajar bersama yang partisipatif, agar terjadi perubahan perilaku pada diri semua stakeholders (individu, kelompok dan kelembagaan) yang terlibat dalam proses pembangunan demi terwujudnya kehidupan yang semakin berdaya, mandiri dan partisipatif yang semakin sejahtera secara berkelanjutan." Pemberdayaan masyarakat adalah upaya untuk meningkatkan harkat dan martabat golongan masyarakat yang sedang kondisi miskin, sehingga mereka dapat melepaskan diri dari perangkap kemiskinan dan keterbelakangan. Pemberdayaan adalah upaya untuk membangun kemampuan masyarakat, dengan mendorong, memotivasi, untuk mengembangkan potensi itu menjadi tindakan nyata. Konsep ini mengambarkan pandangan baru tentang pembangunan. ${ }^{10}$ Menurut Agus Effendi ${ }^{11}$ ada tiga bentuk pemberdayaan yang harus diutamakan saat ini, yaitu pemberdayaan ruhaniah, intelektual dan ekonomi. Proses pemberdayaan membutuhkan waktu yang panjang supaya mencapai tujuan dari pemberdayaan itu sendiri .

\section{Pelaksanaan Pemberdayaan Masyarakat Melalui Kelompok Pembudidaya Ikan}

1. Tahap penyadaran terhadap pola pikir masyarakat

Dalam meningkatan kesejahteraan masyarakat diperlukan pola pikir yang matang, sebab pola pikir akan membentuk perilaku, sikap dan tanggung jawab dalam kehidupan bermasyarakat. Manusia diciptakan untuk berfikir tentang kehidupan di dunia ini dan akan mengalami perubahan sering perkembangan zaman dan akan terus bergerak untuk mencapai kebahagiaan dalam hidupnya, jika perubahan akan dilakukan

${ }^{8}$ Sudjana, Nana, Dasar-dasar Proses Belajar Mengajar, (Bandung: Sinar Baru Algensido Offset, 2004), hlm. 264 100 30

9 Mardikanto T dan Soebiato P, Pemberdayaan Masyarakat, (Bandung: Alfabeta, 2013), hlm.

${ }^{10}$ Zubaedi, Pengembangan Masyarakat, (Jakarta: Kencana Prenada Media Group, 2013), hlm.

11 Nanih Machendrawaty dan Ahmad Safe'i, Agus, Pengembangan Masyarakat Islam Dari Ideology, Strategi Sampai Tradisi, (Bandung: PT Remaja Rosdakarya, 2001), hlm. 44 
7 Iswadi, Pemberdayaan Masyarakat Melalui Pembinaan Kelompok Perikanan Dalam Meningkatkan Kesejahteraan Masyarakat

Jurnal At-Taghyir : Jurnal Dakwah dan Pengembangan Masyarakat Desa

Volume 2 Nomor 1 Desember 2019, h. 1-13

pada konteks kehidupan masyarakat bukanlah sesuatu hal yang mudah dan segampang dari apa yang dipikirkan. Merubah perilaku dan pola pikir masyarakat membutuhkan usaha dan proses yang panjang dan konsep yang matang. Kelompok pembudidaya ikan (pokdakan) "mandiri saiyo" berusaha untuk berubah pola pikir masyarakat, bahwasanya melakukan budidaya ikan bisa meningkatkan kesejahteraan masyarakat.

Kegiatan-kegiatan pemberdayaan masyarakat melalui kelompok pembudidaya ikan (pokdakan) yang dilakukan oleh kelompok pembudidaya ikan "mandiri saiyo adalah melakukan pembentukan sikap peduli dan pola pikir untuk peningkatan kesejahteraan melalui budidaya ikan. Pada tahap ini kelompok pembudidaya ikan "mandiri saiyo" mempromosikan kepada tokoh-tokoh masyarakat tentang keunggulan dalam berbudidaya ikan. Dengan perjuangan yang intens dan melelahkan pikiran berdiskusi dengan orang-orang yang masih belum bisa sepenuhnya menerima perubahan-perubahan, namun berkat usaha dari anggota kelompok mandiri saiyo beserta dinas pangan dan perikanan pada saat ini masyarakat telah banyak melirik bagaimana cara berbudidaya ikan, ini dibuktikan dengan banyaknya masyarakat yang berminat berbudidaya ikan dengan membentuk kelompok-kelompok pembudidaya ikan dan ada juga yang secara pribadi-pribadi. Pada saat ini jumlah kelompok pembudidaya ikan di Jorong Andaleh sudah ada 6 (enam) kelompok, awalnya hanya ada satu kelompok. Dengan bertambahnya jumlah kelompok pembudidaya ikan tentu diharapkan ekonomi masyarakat dalam beberapa tahun selanjutnya akan berkembang secara baik.

2. Tahap Transformasi Wawasan Pengetahuan

Dalam meningkatkan kemampuan wawasan anggota pembudidaya ikan perlu di berikan sebuah pengetahuan, cara budidaya ikan yang sesuai dengan CBIB. Pemberikan wawasan pengetahuan tentang budidaya perikanan bertujuan agar anggota memiliki kemampuan dalam bidang membudidayakan perikanan sehingga tujuan dari bedirinya kelompok pembudidaya ikan tercapai dengan baik. Kemampuan yang di peroleh oleh anggota melalui pemberian wawasan pengetahuan memberikan dampak yang signifikan dalam membudidayakan ikan. Pemberian wawasan pengetahuan tentang tatacara budidaya ikan yang baik dan benar, cara membuat pakan ikan serta cara penanganan hama di sampaikan oleh dinas pangan dan perikanan Kabupaten Tanah Datar kepada setiap kelompok pembudidaya ikan dengan mengutus beberapa orang dan nantinya 
8 Iswadi, Pemberdayaan Masyarakat Melalui Pembinaan Kelompok Perikanan Dalam Meningkatkan Kesejahteraan Masyarakat

Jurnal At-Taghyir : Jurnal Dakwah dan Pengembangan Masyarakat Desa

Volume 2 Nomor 1 Desember 2019, h. 1-13

informasi yang didapat dalam pelatihan disampaikan kepada anggota lainnya yang tidak datang, sehingga merata ilmu yang diberikan kepada masyarakat, dari pemberian wawasan pengetahuan tersebut pembudidaya ikan mengetahui apa yang selama ini salah atau kurang benar dalam penanganan atau perlakuan terhadap cara budidaya ikan. Dari pelatihan tersebut kelompok pembudidaya ikan diharapkan pembudidaya ikan dapat meningkatkan hasil produksinya.

\section{Tahap Peningkatan Keterampilan}

Pemberdayaan atau pengembangan masyarakat memiliki pengertian "pembangunan masyarakat (community development) dan pembangunan yang bertumpu pada masyarakat (community-based development) Chamber tahun $1995 .{ }^{12}$ Pendekatan utama dalam konsep pemberdayaan adalah bahwa masyarakat tidak dijadikan obyek dari berbagai proyek pembangunan, tetapi merupakan subyek dari upaya pembangunannya sendiri. Pembangunan partisipatif mempunyai kaitan yang erat dengan pemberdayaanmasyarakat, dimana pada pembangunan partisipatif diperlukan upaya dan langkah-langkah untuk mempersiapkan masyarakat guna memperkuat kelembagaan masyarakat agar mereka mampu mewujudkan kemajuan, kemandirian, dan kesejahteraan dalam suasana keadilan yang berkelanjutan untuk meningkatkan harkat dan martabatnya serta mampu melepaskan diri dari perangkap kemiskinan dan keterbelakangan. Upaya tersebut merupakan salah satu wujud nyata dari pemberdayaan masyarakat. $^{13}$

Pemberdayaan masyarakat sebagai sebuah strategi, sekarang telah banyak diterima, bahkan telah berkembang dalam berbagai literature di dunia barat. Pemberdayaan masyarakat adalah sebuah konsep pembangunan ekonomi yang merangkum nilai-nilai sosial. Secara konseptual, pemberdayaan masyarakat adalah upaya untuk meningkatkan harkat dan martabat lapisan masyarakat yang dalam kondisi sekarang tidak mampu untuk melepaskan diri dari perangkap kemiskinan dan

\footnotetext{
${ }^{12}$ Kartasasmita, Ginanjar, Administrasi Pembangunan, (Jakarta, LP3ES, 1997), hlm. 41

13 Sumaryadi, I Nyoman, PerencanaanPembangunan Daerah Otonom dan Pemberdayaan Masyarakat, (Jakarta: Penerbit Citra Utama, 2005), hlm. 111
} 
9 Iswadi, Pemberdayaan Masyarakat Melalui Pembinaan Kelompok Perikanan Dalam Meningkatkan Kesejahteraan Masyarakat

Jurnal At-Taghyir : Jurnal Dakwah dan Pengembangan Masyarakat Desa

Volume 2 Nomor 1 Desember 2019, h. 1-13

keterbelakangan. Dengan kata lain memberdayakan adalah memampukan dan memandirikan masyarakat. ${ }^{14}$

Pelaksanaan peningkatan keterampilan kelompok pembudidaya ikan (pokdakan) "mandiri saiyo" adalah pertama mengikuti pelatihan yang diselenggarakan oleh dinas pangan dan perikanan kabupaten tanah datar, pelatohan yang diberikan oleh dinas pangan dan perikanan kabupaten Tanah Datar adalah memberikan materi tentang tata cara berbudidaya ikan sesuai CBIB, pengendalian hama, tata cara pembuatan pakan ikan. Setelah wawasan pengetahuan diberikan oleh dinas pangan dan perikanan selanjutnya diberikan bibit dan benih ikan bertujuan untuk mengaplikasikan wawasan pengetahuan yang telah di berikan tersebut.

Dinas pangan dan perikanan selalu memantau kelompok pembudidaya ikan (pokdakan) "mandiri saiyo" terhadap apa yang telah diberikan dan hasilnya alhamdulillah memuaskan. Melihat hal tersebut dinas pangan dan perikanan memberikan bantuan mesin pembuat pakan ikan. apa yang telah dilakukan oleh kelompok pembudidaya ikan (pokdakan) "mandiri saiyo" dan dinas pangan dan perikanan memberikan stimulus, motivasi bagi masyarakat untuk berbudidaya ikan. dan sekarang masyarakat telah mulai kembali memanfaatkan kolam atau lahan mereka yang bisa di pakai untuk budidaya ikan. dari hal tersebut diharapkan kesejahteraan masyarakat meningkat.

Dari hasil penelitian pemberdayaan masyarakat melalui kelompok pembudidaya ikan (pokdakan) "mandiri saiyo" merupakan usaha yang dilakukan untuk meningkatkan kesejahteraan, pemerataan sosial, mengurangi kemiskinan, menambah wawasan dan mengurangi pengangguran. Makna dari Pemberdayaan adalah membangkitkan kekuatan (power), keterampilan, pengetahuan dan kesempatan untuk meningkatkan kesejahteraan dan masa depan. Pemberdayaan masyarakat memiliki tujuan untuk membentuk individu dan masyarakat menjadi mandiri. ${ }^{15}$ Usaha-usaha yang dilakukan oleh kelompok pembudidaya ikan dan dinas pangan dan perikanan merupakan salah satu bentuk

\footnotetext{
${ }^{14}$ Theresia, Aprilia, Pembangunan Berbasis Masyarakat: Acuan Bagi Praktisi, Akademisi, dan Pemerhati Pengembangan Masyarakat, (Bandung: Alfabeta, 2005), hlm. 91-93

${ }^{15}$ Sulistyani, Ambar Teguh, Kemitraan dan Model-Model Pemberdayaan, (Yogyakarta: Gava Media, 2004), hlm. 30
} 
10 Iswadi, Pemberdayaan Masyarakat Melalui Pembinaan Kelompok Perikanan Dalam Meningkatkan Kesejahteraan Masyarakat

Jurnal At-Taghyir : Jurnal Dakwah dan Pengembangan Masyarakat Desa

Volume 2 Nomor 1 Desember 2019, h. 1-13

pemberdayaan yang berbasis kelompok walaupun masih banyak ditemukan kekurangankekurangan pada pemberdayaan tersebut.

\section{Faktor pendukung dan penghambat}

1. Faktor Pendukung

Dalam rangka memperkuat kelompok pembudidaya ikan dan membentuk pola pikiran masyarakat serta peningkatan ekonomi masyarakat pada umumnya dan kelompok pada khususnya. Berdasarkan temuan dilapangan terdapat factor-faktor pendukung pelaksanaan pemberdayaan masyarakat melaui kelompok pembudidaya ikan yaitu:

a. Dukungan dari pemerintah yang memfasilitasi terbentuknya kelompok pembudidaya ikan " mandiri saiyo". peran dari pemerintahan daerah untuk membantu terbentuknya kelompok perikanan, memberikan pelatihan-pelatihan terkait bagaimana cara budidaya ikan yang sesuai CBIB, serta bagaimana cara mengelola kelompok budidaya ikan agar ekonomi anggota meningkat. Disamping itu juga dinas pangan dan perikanan kabupaten tanah datar juga memberikan pelatihan bagaimana cara membuat pakan. Selain dukungan dalam bentuk pelatihan-pelatihan dinas pangan dan perikanan kabupaten tanah datar juga memberikan bantuan bibit ikan, pakan dan mesin pembuat pakan untuk kelompok pembudidaya ikan.

b. Dukungan dari masyarakat, dalam program pemberdayaan masyarakat dibutuhkan dukungan dari stake holder dan tokoh masyarakat. Arahan dan partisipasi dari stake holder dapat memberikan nilai positif dan semangat dari anggota kelompok pembudidaya perikanan untuk meningkatkan kesejahteraan.

c. Antusias masyarakat, dengan adanya Kelompok pembudidaya ikan "mandiri saiyo", telah memacu antusiasme warga Nagari Andaleh Baruh BUKIK untuk turut serta membuat kelompok kelompok perikanan dalam menciptakan atau mengembangkan budidaya perikanan yang hasilnya diharapkan dapat membawa kebaikan dan kesejahteraan bagi perekonomian anggota pada khususnya dan masyarakat pada umumnya. Dan juga masayrakat telah banyak memanfaatkan kembali kolomnya yang selama ini terabaikan. 
11 Iswadi, Pemberdayaan Masyarakat Melalui Pembinaan Kelompok Perikanan Dalam Meningkatkan Kesejahteraan Masyarakat

Jurnal At-Taghyir : Jurnal Dakwah dan Pengembangan Masyarakat Desa

Volume 2 Nomor 1 Desember 2019, h. 1-13

d. Lokasi yang strategis. Nagari Andaleh Baruh Bukik yang dikelilingi oleh perbukitan banyak ditemukan sumber air yang banyak, sehingga cocok digunakan untuk budidaya perikanan karena kesediaan airnya yang cukup walaupun pada musim kemarau.

2. Faktor yang mempengaruhi program pemberdayaan

Ada beberapa faktor yang menjadi kurang lancarnya program pemberdayaan kelompok pembudidaya ikan "mandiri saiyo" adapun faktor penghambatnya adalah sebagai berikut:

a. Manajemen organisasi, dalam hal ini, masih kurang perhatian dari pengurus menyangkut administrasi, dokumentasi, arsip serta kurangnya tanggungjawab dari berbagai pihak, menyangkut kemajuan kelompok, akhirnya hanya terfokus kebeberapa orang saja.

b. Kesadaran dalam berkelompok, kurangnya sumbangsih anggota kelompok dalam mensukseskan program-program, misalnya: gotong royong, iuran, tidak menghadiri pertemuan/rapat.

c. Kerjasama para anggota, kerjasama pada masing-masing anggota kurang, ini ditandai hanya beberapa orang yang berjibaku terhadap kegiatan, sehingga ada kecemburuan sosial yang timbul, sehingga bisa merusak kekompakan dalam berkelompok.

d. Pemasaran. Pada saat panen, kelompok pembudidaya ikan mengalami kesulitan dalam memasarkan hasil panennya. Dalam hal ini dibutuhkan peran pemerintah untuk menfasilitasi masyarakat pembudidaya ikan agar mereka dapat dengan mudah memasarkan hasil dari budidaya mereka.

e. Pakan. Pakan ikan yang mahal juga ikut andil dalam mempengaruhi keberlanjutan dari kelompok pembudidaya ikan. 
12 Iswadi, Pemberdayaan Masyarakat Melalui Pembinaan Kelompok Perikanan Dalam Meningkatkan Kesejahteraan Masyarakat

Jurnal At-Taghyir : Jurnal Dakwah dan Pengembangan Masyarakat Desa

Volume 2 Nomor 1 Desember 2019, h. 1-13

\section{E. Penutup}

Dalam meningkatkan kesejahteraan dan mengatasi berbagai persoalan yang dihadapi oleh masyarakat, maka diperlukan tindakan nyata untuk mengatasi berbagai persoalan yang ada di tengah masyarakat yaitu dengan melakukan pemberdayaan di semua lini kehidupan. Bentuk-bentuk Pemberdayaan masyarakat yang terjadi pada kelompok pembudidaya ikan mandiri saiyo adalah pertama, merubah pola pikir masyarakat, kedua, memberikan pengetahuan seputar tata cara budidaya ikan dan ketiga, dengan memberikan keterampilan. Dengan hadirnya kelompok pembudidaya ikan mampu memberikan stimulus kepada masyarakat banyak untuk berbudidaya ikan dan juga dibutuhkan peran pemerintah dalam memberikan solusi terhadap persoalan yang dihadapi oleh kelompok pembudidaya ikan. 
13 Iswadi, Pemberdayaan Masyarakat Melalui Pembinaan Kelompok Perikanan Dalam Meningkatkan Kesejahteraan Masyarakat

Jurnal At-Taghyir : Jurnal Dakwah dan Pengembangan Masyarakat Desa

Volume 2 Nomor 1 Desember 2019, h. 1-13

\section{Daftar Kepustakaan}

Al-Quran in Word, 2007. QS. Ar-Ra'd: 11

Arif Eko Wahyudi Arfianto dkk, "Pemberdayaan Masyarakat Dalam Pembangunan Ekonomi Desa," JKMP, (2) No.1, 2014.

Burhan Bungin. “Analisis Data Penelitian Kualitatif”. Jakarta: Raja Grafindo. 2006

Hikamat, Harry, Strategi Pemberdayaan Masyarakat, Bandung : Humaniora KBBI v1.1.

Kartasasmita, Ginanjar, “Administrasi Pembangunan”. Jakarta, LP3ES. 1997

Munawar Noor, "Pemberdayaan Masyarakat,” Jurnal Ilmiah CIVIS, (1) No. 2, 2011.

Mardikanto T dan Soebiato P.” Pemberdayaan Masyarakat”. Bandung, Alfabeta, 2013

Machendrawaty, Nanih dan Ahmad Safe'i, Agus. "Pengembangan Masyarakat Islam Dari Ideology, Strategi Sampai Tradisi”. Bandung: PT Remaja Rosdakarya. 2001.

Sudjana, Nana. "Dasar-dasar Proses Belajar Mengajar". Bandung: Sinar Baru Algensido Offset. 2004

Sulistyani, Ambar Teguh. "Kemitraan dan Model-Model Pemberdayaan”. Yogyakarta: Gava Media. 2004

Statistik Daerah Kabupaten Tanah Datar. BPS Kab. Tanah Datar. 2017.

Sumaryadi, I Nyoman. "PerencanaanPembangunan Daerah Otonom dan Pemberdayaan Masyarakat", Jakarta: Penerbit Citra Utama. 2005

Theresia, Aprilia. "Pembangunan Berbasis Masyarakat (Acuan Bagi Praktisi, Akademisi, dan Pemerhati Pengembangan Masyarakat)". Bandung: Alfabeta. 2014

Wrihatnolo, Randhy R. Manajemen Pemberdayaan. Jakarta: PT Elex Media Komputindo. 2007.

Zubaedi. "Pengembangan Masyarakat, Wacana dan Praktik". Jakarta: Kencana. 2013 